\title{
DYNAMICS AND DIRECTIONS OF DEMOGRAPHIC CHANGES IN BOSNIA AND HERZEGOVINA
}

\author{
Stevo Pašalić ${ }^{\text {, Drago Vuković }}{ }^{2}$, Miladin Jovičić ${ }^{3}$, Dalibor Stević ${ }^{4}$ \\ ${ }^{1}$ Prof. Dr., Univerzitet u Istočnom Sarajevu, stevo.pasalic@gmail.com \\ ${ }^{2}$ Prof. Dr., Universizet u Istočnom Sarajevu, dragovukovic55@gmail.com \\ ${ }^{3}$ Prof. Dr., Univerzitet u Istočnom Sarajevu, miladinjovicic@yahoo.com \\ ${ }^{4}$ Prof. Dr., Univerzitet u Istočnom Sarajevu, daco@gmail.com
}

\begin{abstract}
Population of $\mathrm{BiH}$ as a whole and its lower territorial units depends on the birth rate and migration balance. Suprapopulation (population growth) is present in a very small number of territorial units (villages and municipalities), while depopulation (decrease of population) has affected a large number of spatial units. During the recent times, industrialization, agrarian reform and urbanization led to the migration and depopulation of biological type in rural areas in the last 30 years. Cities, as opposed to rural areas, have had so far superpopulation, noting that now in some of them there is a biological depopulation. The form of simple renewal of the population in BiH has changed in the late 80's of the last century. There are numerous causes of migration in the territory of $\mathrm{BiH}$, but the economic and political and a security reasons were the most important. The migration demographic losses were greatest in the total demographic losses. As a result of biovitalitent, biodynamic and migration processes and relations in $\mathrm{BiH}$, dominated by the depopulation spatial units, spread to over more than $3 / 4$ of its territory. Depopulation and aging are two related demographic processes that most influence the demographic development of an area. Depopulation encouraged by emigration and low fertility is generally characterized as a problem, especially for smaller territorial units that are faced with the process of demographic extinction. Demographic change cannot be solved by partial measures and small reforms. Major reforms, which will compensate population decline and aging population, will be plenty painful. Social situation for future generations will be quite different and very uncertain looking from today's position.
\end{abstract}

Keywords: suprapopulation, depopulation, migration, birth rate, demographic changes

\section{INTRODUCTION}

The demographics of some area and demographic change are factors that have traditionally been considered as a result and not a cause of socio-economic change. Perhaps this contributed to the fact that the demographic processes are relatively slow and fairly predictable and unlike many other factors that affect the socio-economic development of an area, their effect is usually manifested in the long run. It is important to emphasize that demographic movements are at the same time a precondition but also the limit of spatial development, labor market functioning and polycentric economic and social development. The number of inhabitants of each territory depends on the natural increase and migration flows. However, in unforeseen circumstances (earthquakes, floods and other natural disasters, wars, etc.), it causes the accelerated population decline. 
The existence or non-existence of these processes can lead to depopulation or suprapopulation. Bosnia and Herzegovina after the Second World War to the end of the eighties was in the process of suprapopulation (the highest rate of population growth after Macedonia in the former Yugoslav republics). Over time, due to industrialization, agrarian reform and urbanization, that leads to depopulation in rural areas. Cities, as opposed to rural areas, had until recently overall suprapopulation, but now in some of them natural depopulation has appeared.

System display of demodynamic elements and their relations in the process of changing population of a certain territory is reflected in suprapopulation (population increase), depopulation (natural, emigration, total) and migration (emigration, immigration).

Quantitative dynamic model of change in the number of inhabitants (for suprapopulation) obtained using the formula: $r=(\sqrt{2}-1) .1,000$ and $r=(\sqrt{ } 0,5-1) .1,000$ for depopulation. At the end of the eighties $\mathrm{BiH}$ had one of the specific phase of its demographic development. The pattern of recovery of the population has changed (below the level of simple reproduction), and later the war broke out, which particularly affected demographic trends.

Understanding the demographic development cannot be based only on questionable statistics, in view of population relations in society and space stochastic and often invisible and undetectable. An assessment of demographic revitalization potential and setting up demographic problems in the basics of development and survival is of strategic importance for $\mathrm{BiH}$.

The demographic picture of Bosnia and Herzegovina in the 21 st century is reflected in a number of specific processes: natural depopulation, or a larger number of deaths than births, an aging population and imbalances in the age structure of the population, a continuous increase in life expectancy at birth and the negative balance of net migration from abroad. Depopulation is a demographic phenomenon that affects the spatial development. Depopulation is a demographic phenomenon that affects the spatial development. The population of $\mathrm{BiH}$ is reduced and the process of depopulation is affecting many regional and local spatial units. Joint action of low fertility, distorted age structure and migration of young people of reproductive age has led to the beginning of the process of extinction of many areas. In the current conditions of economic standstill, even under conditions of slow development, these demographic trends affect the growth of poverty. The demographic problem is more in terms of the demographic transition, transition economies and the economic recession in $\mathrm{BiH}$ are transforming into a serious social and economic problem.

\section{THE METHODOLOGICAL FRAMEWORK RESEARCH}

It should be noted that the censuses in 1971, 1981, 1991 were done according to the principle of permanent (de jure) population. By contrast, in the census of 2013 a new concept was applied, ie. the concept of the present (de facto) of the total population, but slightly changed in relation to its original meaning. This results in a discrepancy between the lists (a significant decline in population censuses in the period 1991 - 2013).

In the study of natural population growth, the data of vital statistics were used. These data include only the natural movement of population in the country, in order to avoid discrepancies in values of indices of natural population dynamics.

Being aware that all demographic problems with its content cannot be classified in the combined group, and that some of them remain out of them, we have classified demographic statistical methodological characteristics into three basic groups:1) characteristics of the typology in connection with aims of demographic research, 2) statistical sources and their credibility, 3) the application and interpretation of statistical indicators.

The first group of questions is not exclusively demographic, although it makes one of the prerequisites of each demographic research. Statistical sources are the restraining factors of demographic research on the almost entire territory of $\mathrm{BiH}$. In the example of an entity that is more pronounced, because of the research unit due to historic changes and administrative arrangement of the country.

The third set of questions can be linked to the problem of statistical indicators and their interpretation in the case of "small population" which belong to almost all rural areas in $\mathrm{BiH}$. The problem is accentuated by the existence of long and intensive large part of the depopulation of rural areas, so you must modify the usual grading criteria and modalities of depopulation and its consequences (special distinction old population by age).

The key theoretical question of demographic analysis of the development of $\mathrm{BiH}$ population is their classification into the "open" or "closed" population model. The basic meaning of "open" model is the presence of both components of the total population movements (natural and mechanical), while in the 
"closed" model of quantitative and qualitative aspects of population it occurs under the exclusive influence of natural movement.

Latterly, methods to measure migration are getting more attention and understanding their very important role in the spatial dynamics of the total population, while developing its own methodology of demography research, forecasting and planning. Migration, with the birth rate (fertility) and mortality rates are among the key determinants of the population. This kind of interdependence is common to observe the condition of mortality and fertility, to directing and developing measures in the field of migration. Therefore, the migration can be very successfully applied to the concept of the common elements of analysis of mortality and fertility, adapted to the problem of measuring migration. The current demographic studies, in addition to the quantitative approach to migration flows, considerably pay attention to the issue of study and selection of migrants according to various characteristics (gender, age, education) as well as demographic, economic and social characteristics of migration.

Migration is an event in time and depends on the length of the interval: $M i=f 0(t, e)$. The influence of the stochastic component (e) is added as a function of additive member. A key determinant of demographic migration is the structure of the population. There is a primarily age and gender, but also the educational structure of the population. Each of these structures is relevant for making demometric migration model, if empirical data quality is available.

Migration is understood in its spatial dimension, regularly causing disturbances in the age and gender structure of the population because of the special characteristics of migrants by age and gender. The age structure can be expressed using the variables age (d) at a given time $(\mathrm{t})$. Migration, in fact, depends on the age structure of the population in a certain time $(t)$, which can be expressed by the relation $\mathrm{Mi}=\mathrm{f} 1(\mathrm{~d}, \mathrm{t}, \mathrm{s})$

Most migrants are young (Rogers, 1976). Migration consists primarily of young people, the core business and the fertile contingent, the age cohort of 20 to 40 years.

Linear demometric model is a common model which expresses relations between phenomena. Such models are important, a constant characteristic: the presence of the stochastic component. In practice models can be used with two variables or more. The most common is a demographic variable included in the model that depends on the weather, or a demographic variable that depends on other demographic and nondemographic variables. In this case, the connection between such demographic variables may show different forms of analytical models.

\section{RESEARCH RESULTS}

\subsection{Characteristics of main demodynamic elements}

Natural increase, apropos biovitality is the main element of the survival of a nation. When it becomes negative, unless there is immigration, that leads to a decrease in population. If the annual rate of population growth $-4.61^{0} \%$, the number of inhabitants of a certain territory dimidiates for 150 years.

The rate of $-9,2 \%$ corresponds to a period of 75 , a rate of $-13.77 \%$ period of 50 years. If the rate of population growth $-27.350 \%$, the number of inhabitants of a double reduction and dimidiates for 25 years, ie . for one generational gap. Conversely, if the rate of natural increase, for example, $35,26 \%$, then the population will double in 20 years. An annual rate of $6,96 \%$ corresponds to a doubling period of 100 , a rate of $3,47 \%$, of 200 and a rate of $1,39 \%$ period of 500 years.

Before presenting data on major demodynamic elements we provide an overview of the degree of agrarian reform and urbanization in Bosnia and Herzegovina.

Chart 1. Percentage share of agricultural and urban of the total population of $\mathrm{BiH}^{1}$

\begin{tabular}{|l|l|l|l|l|l|l|l|}
\hline & 1948. & 1953. & 1961. & 1971. & 1981. & 1991. & 2013. \\
\hline Agricultural in total population & 71,8 & 68,2 & 50,2 & 36,5 & 17,3 & 9,8 & $\ldots$ \\
\hline Urban in total population & 14,3 & 16,3 & 21,0 & 27,9 & 36,2 & 39,5 & 45,0 \\
\hline
\end{tabular}

Source: Statistical yearbook 1993-1998.Federal Bureau of Statistics, Sarajevo

\footnotetext{
${ }^{1}$ Those annual rate of doubling, or double reduction or dimidiation of population were calculated according to the forms listed in the introduction to this work.
} 
It is noticeable that in $\mathrm{BiH}$ after the Second World War an extensive process of deagrarization was carried out. However, it is still in proportion many employed in agriculture comparing to highly developed countries. In addition, in agriculture of $\mathrm{BiH}$ age structure of the labor force , land fragmentation, inadequate cultural practices, etc. are unfavorable.

The level of urbanization in $\mathrm{BiH}$ since 1948 is growing steadily. Particularly an increased concentration of (immigration) population in major cities.

Through data on the agrarian reform and urbanization scope, it is evident that in $\mathrm{BiH}$ in the last 60 years a comprehensive socio-economic process was carried out. In fact, the salient economic and educationalcultural progress was carried out, which left a strong mark and influence on all demographic components, including large population displacement, a change of attitude toward biodynamics, and change the size of the family and household, lifestyle and others.

In order to have causal-correlational relationship between the population and the amount of natural increase better noticed for the main unit of territorial $\mathrm{BiH}$, we give this information in the following charts.

Chart 2. Number and basic territorial structure the population of Bosnia and Herzegovina (in 000)

\begin{tabular}{|l|l|l|l|l|l|l|l|}
\hline & 1948. & 1953. & 1961. & 1971. & 1981. & 1991. & 2013. \\
\hline $\begin{array}{l}\text { Bosnia and } \\
\text { Hercegovina }\end{array}$ & $\begin{array}{l}2,564 \\
100,0\end{array}$ & $\begin{array}{r}2847 \\
100,0\end{array}$ & $\begin{array}{r}3277 \\
100,0\end{array}$ & $\begin{array}{r}3746 \\
100,0\end{array}$ & $\begin{array}{r}4124 \\
100,0\end{array}$ & $\begin{array}{r}4377 \\
100,0\end{array}$ & $\begin{array}{r}3531 \\
100,0\end{array}$ \\
\hline $\begin{array}{l}\text { Republic of } \\
\text { Srpska }\end{array}$ & - & - & - & - & - & 1569 & $\begin{array}{r}1228 \\
34,8\end{array}$ \\
\hline $\begin{array}{l}\text { Federation of } \\
\text { BiH }\end{array}$ & - & - & - & - & - & 2720 & 2219 \\
& & & & & & 62,1 & 62,8 \\
\hline District Brcko & - & - & - & - & - & 88 & 83 \\
& & & & & & 2,0 & 2,4 \\
\hline
\end{tabular}

Source: Statistical yearbook 1993-1998. Federal Bureau of Statistics, Sarajevo 3

BiH Census, Statistical Agency of BiH, Sarajevo, 2016.

The data in Chart 2 show that after the Second World War the number of inhabitants in $\mathrm{BiH}$ increased $72 \%$ in the period from 1948 to 1991 . After the renovation, the new territorial organization of $\mathrm{BiH}$, the first census was held in 2013, whose results are not accepted in the country. According to the census results, the largest number of inhabitants live in the Federation of $\mathrm{BiH}$ (62.5\%), in the Republic of Srpska $35.0 \%$ and in the Brcko District 2.5\%.

Chart 3. Scope and territorial structure of natural increase in Bosnia and Herzegovina (per thousand)

\begin{tabular}{|l|c|c|c|c|c|c|}
\hline & 1953. & 1961. & 1971. & 1981. & 1991. & 2015. \\
\hline BosniaandHercegovina & 26,2 & 22,4 & 14,4 & 10,9 & 8,9 & $-1,5$ \\
\hline Republic of Srpska & - & - & - & - & 7,0 & $-3,8$ \\
\hline Federation of BiH & - & - & - & - & 12,0 & $-0,2$ \\
\hline District Brcko & - & - & - & - & 9,0 & $-0,7$ \\
\hline
\end{tabular}

Source: Statistical yearbook of Yugoslavia 53-91. Statistical bulletin, Statistical Agency of BiH, 2016.

Population growth rate in $\mathrm{BiH}$ was $8.9 \%$ in 1991. a $-1.50 \%$ 2015. The road from high natural growth to depopulation had lasted 54 years (1953 to 2007). Thus, Bosnia and Herzegovina has entered into a process of depopulation of the total since 2007. Reducing the natural population growth rate from 1953 to 1991 was 17,30 / is 00 . It has been decreased for almost a triple. In order to obtain a more complete character of 
natural growth for the organization and realization of the population policy in $\mathrm{BiH}$ (especially by entity) it is necessary to bear in mind that the annual population growth rate has been declining steadily, and there are large geographical differences in the amount of volume and rate of natural increase between the Republic of Srpska, Federation of $\mathrm{BiH}$ and Brcko District. The negative natural increase is particularly widespread in rural areas. In the Republic of Srpska, in 2015, the population growth rate was positive only in the territory of the city of Banja Luka, out of 62 municipal / city territory. Negative natural increase was also in 50 municipalities out of 79 in FBiH, as well as in the District of Brcko.

Chart 4. Population growth rate by ethnicity in Bosnia and Herzegovina

\begin{tabular}{|l|l|l|l|l|l|}
\hline Ethnicity & 1961. & 1971. & 1981. & 1991. & 2015. \\
\hline Bosniaks & 29,5 & 18,6 & 14,8 & 12,0 & 1,6 \\
\hline Croats & 24,8 & 14,7 & 8,9 & 8,0 & $-1,6$ \\
\hline Serbs & 19,6 & 11,3 & 7,7 & 7,0 & $-3,8$ \\
\hline
\end{tabular}

Source: Statistical yearbook of BiH 1961-1991. Statistical Agency of BiH bulletin

Chart 4 shows that there are differences in the rates of natural increase in cultural and traditional, religious and ethnic grounds. Serbs and Croats in $\mathrm{BiH}$ had a higher birth rate than the Serbs and Croats in Serbia and Croatia. Muslims (Bosniaks from 1993) in $\mathrm{BiH}$ had the highest rate of natural increase. So, it is obvious that there are differences in the rate and extent of natural increase between the Islamic and Christian environment. Overall, these rates are constantly decreasing, and the natural growth rate in BiH since 2007 is negative (natural depopulation). Depopulation is a demographic phenomenon that affects the spatial development. The population of $\mathrm{BiH}$ is reduced and the process of depopulation is affecting many regional and local spatial units. Joint action of low fertility, unfavorable age structure and migration of young people of childbearing age has led to the beginning of the process of extinction of many areas in the country.

\subsection{Migration demodynamic component}

In the Balkans, especially in the area where Serbs have lived, migration processes were long and intense. There are numerous causes of migration in the region, but economic, political and security reasons were the most important. Migration caused by economic reasons have lasted for centuries. Bosnia and Herzegovina is a historical emigration space.

$\mathrm{BiH}$ after the Second World War has given the most immigrants, $55,2 \%$ of the total Serb immigrants in Serbia in 1981, came from $\mathrm{BiH}$, and $32.6 \%$ from Croatia, 5.5 times more Serbs emigrated from $\mathrm{BiH}$ than immigrated to it (Pasalic, 2012).

Chart 5. Net migration balance in $\mathrm{BiH}$ 1948-2013. year

\begin{tabular}{|c|c|c|}
\hline Period & $\begin{array}{c}\text { Total net migration } \\
\text { balance }\end{array}$ & Per year \\
\hline 1948.-1952. & -29779 & -5956 \\
\hline 1953.-1960. & -161610 & -20201 \\
\hline 1961.-1970. & -216072 & -21607 \\
\hline 1971.-1980. & -133780 & -13378 \\
\hline 1981.-1990. & -171207 & -17121 \\
\hline $1991 .-2013$. & -935085 & -42504 \\
\hline
\end{tabular}

Source: Calculation by author by vital-statistical method

The percentage of net migration balance of the population is different in certain periods. The smallest was in the interval from 1948 to 1952 , when the average population was $1.1 \%$, and the highest $6.1 \%$ in the period 
1961-1970. However, the percentage of net migration balance in relation to the population growth rate is far higher and the ninth decade exceeds $40 \%$. Therefore, emigration from $\mathrm{BiH}$ has been very significant.

War period in Bosnia (1992-1995)has launched a large displacement of the population with a number of refugee waves and it has determined the atypical enforced substitution of the population, a relatively large scale, as well as the redistribution of population within $\mathrm{BiH}$. Today outside $\mathrm{BiH}$ (in the Diaspora) there is a population of 1.6 million of its inhabitants.

So the censuses between 1991 and 2013. the negative migration balance was the main factor in the general depopulation in $\mathrm{BiH}$, while the natural reduction worked in the same direction, but with a much lower weight. We should therefore emphasize that this is, above all, the war worsening migration balance, which was negative already before. The migration that accompanies war and after the war, especially in terms of the economic recession (in the case of $\mathrm{BiH}$ ) is acting on the direction and intensity of changes in the population and its structure (age-gender, socio-economic, educational, ethnic, and other).

\subsection{Scope and territorial coverage of depopulation process in $\mathrm{BiH}$}

After the Second World War in the former Yugoslavia there have been major social and economic, social and political changes. A quite quick process of agrarian reform and urbanization took place. Along with these global social changes a numerous quantitative and qualitative demographic changes have taken place. Since 1992 (the start of the war in $\mathrm{BiH}$ ) untill now, a large demographic changes have taken place in $\mathrm{BiH}$. Demographic War Losses are one of the most important determinants of the total depopulation of population. Despite methodological limitations to the comparison, however, it is quite accurate to say that the population of Bosnia and Herzegovina in the last inter-census period (1991-2013) is characterized by total depopulation and population decline. In other words, between 1991 and 2013, the population of $\mathrm{BiH}$ has been significantly reduced.

Demographic development of smaller territorial units and regional demographic dynamics significantly depend on vital demographic indicators. While the mortality rate is more or less stable, birth rate / fertility is one that varies from year to year. In this case, the age structure plays an important role, especially in smaller territorial units, when population growth depends a lot on age structure of female population. Consequently, as there are more women in reproductive period there will be a higher birth rate, and the total number of newborns.

Chart 6. Depopulation in BiH 1991-2013²

\begin{tabular}{|l|c|c|c|}
\hline & $\begin{array}{c}\text { Population } \\
1991 .\end{array}$ & $\begin{array}{c}\text { Population } \\
2013 .\end{array}$ & $\begin{array}{c}\text { Depopulation } \\
2013 / 1991 .\end{array}$ \\
\hline $\begin{array}{l}\text { Republic of } \\
\text { Srpska }\end{array}$ & 1569332 & 1228423 & -340909 \\
\hline Federation of $\mathrm{BiH}$ & 2720074 & 2219220 & -500854 \\
\hline Brcko District & 87627 & 83516 & -4111 \\
\hline Total: & 4377033 & 3531159 & -845874 \\
\hline
\end{tabular}

Source: Pasalic, S.(2012). Demographic losses in BiH 1991-2013. Population census in $\mathrm{BiH} 2013$, Statistical Agency of $\mathrm{BiH}$, Sarajevo, 2016

Considering the above information and research about the suffering of the population in $\mathrm{BiH}$ (from multiple sources), direct-war demographic losses in $\mathrm{BiH}$ amount to a minimum of about 110,000, of which about $31.5 \%$ are Serbs, Bosnians, about $60.5 \%$, and $8 \%$ Croats and others (Pašalić, 2012)

Net demographic losses or birth rate losses of the population in Bosnia and Herzegovina during the war and because of the war they are in group of non-directional demographic losses. The base is the methodological starting point to define the size of pure demographic losses, as a relation between birth rates achieved in the reporting period and the expected war birth rate that would be (with lesser or greater probability) realized if

\footnotetext{
2 The actual number of residents is given on the basis of Census 2013 which was not recognized in the Republic of Srpska for registration of non-residents into 196,000 permanent residents $\mathrm{BiH}$.
} 
there was no war and that can be calculated on the basis of previous natural dynamics of the population.

Migration demographic losses mean losses of population due to war-induced increased emigration from the country. Due to its size, spatial outcome, and structural-demographic characteristics they have caused complex and unfavorable, short-term and long-term effects on the population and socio-economic development of $\mathrm{BiH}$ as a whole. In assessing the impact of demographic categories of shown losses in the occurrence and development of natural and total depopulation of Bosnia and Herzegovina between 1991 and 2013, it is especially important to note that due to deficiencies and lack of reliable sources of information, it was impossible to fully quantify the size of the demographic losses and its short-term and long-term impacts on the dynamic-structural development of the $\mathrm{BiH}$ population.

Chart 7. Percentage share of depopulated municipalities/towns the total number of municipalities / towns in $\mathrm{BiH}$

\begin{tabular}{|l|l|l|l|l|}
\hline & 2000. & 2006 & 2010. & 2015. \\
\hline Bosnia and Herzegovina & 33,8 & 62,0 & 69,0 & 78,8 \\
\hline Republic of Srpska & 48,4 & 83,9 & 88,7 & 98,4 \\
\hline Federation of $\mathrm{BiH}$ & 22,8 & 45,6 & 54,4 & 63,3 \\
\hline District Brcko & 0,0 & 0,0 & 0,0 & 100,0 \\
\hline
\end{tabular}

Source: Statistical bulletin 2016.RZS Banja Luka, Statistical bulletin 2016, FZS, Sarajevo

The depopulation process in 142 municipalities / cities in BiH (including Brcko District) is the most widespread in the Republic of Srpska. Natural depopulation is occurring since 2002, while the population growth rate in the Federation of $\mathrm{BiH}$ is almost at zero level $(-0.20 / 00)$. Over time depopulation process has expanded, and the $\mathrm{BiH}$ as a whole entered into the overall process of depopulation since 2007 . Only four out of population of larger municipalities in the Republic of Srpska has recorded an absolute increase in population 1991/2013. These are: Banja Luka, Bijeljina, Laktasi and Pale. In the Federation of BiH these municipalities were also scarce. Out of ten cantons, seven ones have a negative natural increase. The depopulation process is particularly widespread in mountainous areas of Bosnia and Herzegovina. In the Republic of Srpska it can be divided by line Novi Grad - Prijedor - Banja Luka - Doboj - Bijeljina - Zvornik, the northern of this line is dense population, and the southern is quite pronounced as demographic discharge, especially in the Federation of $\mathrm{BiH}$ cantons with majority of Croatian population (Canton 10 - Livno, Herzegovina-Neretva, Posavina and Podrinje with Bosniak majority).

Given that the population is the main factor of socio-economic development of certain countries (territories), through the analysis of selected demographic variables and calculating the index of demographic resources, we conducted the evaluation and comparison of the demographic potential in the context of lower territorial units in $\mathrm{BiH}$.

Chart 8. Values of demographic index

\begin{tabular}{|l|c|c|c|c|c|}
\hline \multicolumn{1}{|c|}{ Territory } & $\mathrm{ip}_{\mathrm{n}} / \mathrm{p}(\mathrm{n} 1)$ & $\mathrm{p}(0-14)$ & $p . f 20-29$ & $\mathrm{I}_{\mathrm{v}}$ & $\mathrm{I}_{\mathrm{o}}$ \\
\hline BosniaandHercegovina & 0,81 & 15,4 & 13,0 & 0,78 & 46,1 \\
\hline Republic of Srpska & 0,78 & 14,2 & 12,0 & 60,7 & 41,1 \\
\hline Federation of $\mathrm{BiH}$ & 0,81 & 16,1 & 13,6 & 0,89 & 49,9 \\
\hline District Brcko & 0,95 & 15,9 & 12,4 & 0,85 & 33,1 \\
\hline
\end{tabular}

Source: Calculation by author based on data of statistical resource of $\mathrm{BiH}$

Relative intercensal change of population (coefficient of dynamics), IBP / P ( $n$ 1), points out the general direction of demographic changes in the past, and the trend of demographic and overall development of the observed lower territorial units (the Entities and the District) or a substantial demographic population decline. 
The participation of young (prefertile) population (aged 0-14 years) in the total population according to the reference list, $p(0-14)$ shows the essential role of the contingent, directly qualifying the general fertility rate, and it is reflected in the consideration of biological resources (young people) and age of the population of a territorial unit.

The participation of the younger female fertile contingent (female population aged 20-29 years) in the total female contingent according to the reference list, $p, f(20-29)$ is a component of the demographic index which together with the previous is the most important indicator of the demographic potential of an observed territorial units.

Vitality index (Iv) represents a complex synthetic indicator of actual and potential population biodynamics, since it is based on a synthesis between indicators of natural movement of population (general fertility rate $f$ and general mortality rate $\mathrm{m}$ ) and indicators of the age structure of the population (age index (is) and participation of the younger contingent of mature population aged 20-39 years in the total population. Accordingly, the vitality index is used to evaluate the level of the age of the population and the degree of aging populations (Wertheimer-Baletić, 1999).

The index of education for $\mathrm{BiH}$ and lower territorial spaces, according to the reference list, is different. Looking at a lower territorial areas, this difference varies between 33.1 (DB) to $49.9(\mathrm{FBiH})$. The index for the level of education of $\mathrm{BiH}$ is 46.1 , which is lower than the $\mathrm{FBiH}$ and $\mathrm{RS}$, and greater than DB. Overall, unfavorable demographic development with a large territorial disproportion is the essential characteristic of $\mathrm{BiH}$. To revitalize the area and more balanced demographic development, it is necessary to create conditions for the implementation of clearly defined measures on local and entity level, in the field, above all, population policies, and provide adequate technical support by scientific institutions. In fact, the current situation can be mitigated, but the process of demographic recovery and stopping adverse trends is very long and uncertain.

Chart 9. Model of birth optimum in $\mathrm{BiH}$ according to the queue of child birth (2015.)

\begin{tabular}{|c|c|c|c|c|c|c|}
\hline \multirow{2}{*}{$\frac{\text { Birth line }}{1}$} & \multicolumn{2}{|c|}{$\begin{array}{c}\text { State } \\
\% \text { female child birth }\end{array}$} & $\begin{array}{r}\text { Optin } \\
\text { \% femal }\end{array}$ & $\begin{array}{l}\text { m model } \\
\text { child birth }\end{array}$ & \multicolumn{2}{|c|}{$\begin{array}{c}\text { Deficit } \\
\% \text { child birth }\end{array}$} \\
\hline & 47,6 & 13759 & 52,0 & 20800 & $-33,8$ & -7041 \\
\hline 2 & 36,9 & 10666 & 30,0 & 12000 & $-11,1$ & -1334 \\
\hline $3+$ & 15,5 & 4481 & 18,0 & 7200 & $-37,8$ & -2719 \\
\hline Total & 100,0 & 28906 & 100,0 & 40000 & $-27,7$ & -11094 \\
\hline
\end{tabular}

Source: Calculation by author based on data od vital-statistical method, Statistical Agency

Table 9 shows that the only progression from the first to the second child is satisfactory. The biggest problem is the lack of birth at all, then the progression from the second to the third child. A question to answer of a problem of insufficient births in $\mathrm{BiH}$ (in the Republic of Srpska specially), however, it is extremely complex due to the lack of knowledge in terms of achieving the level of births required to restore generation. The experience of developed countries shows that, despite the significant differences in the economic, sociopolitical and value systems, as well as the institutional basis of population policy, there is a significant degree of uniformity in terms of goals, directions of measures, as well as the definitive expression of the measures. However, the maximum determined effect is an increase of completed fertility by $10 \%$. Consideration of insufficient efficiency measures that have been implemented, indicates that the political answer to this question must be intense, comprehensive, explorative, direct, long-term, strategic type.

The analysis of general birth rate in $\mathrm{BiH}$ shows evidently that it belongs to the low rate (about $8.6 \% 0$ ), which applies to the gross fertility rate. The strategic goal of $\mathrm{BiH}$ and its lower territorial units is reaching the level of the so-called stationary population (equal number of births and deaths), and the preservation of the existing contingent of the population. In order to achieve this goal, now it is necessary more than 11000 children to be born annually.

Basic assumptions of objectively necessary revitalization of the population in $\mathrm{BiH}$ that would stop the extinction and substitution of the local population in the existing social, political and economic terms, can be reduced to that the institutions of $\mathrm{BiH}$ and its entities have demographic problems set at the level of strategic 
national importance, of which depends its overall development and preservation of all values. Accepting the revitalization model of some countries in the world, but with different parameters for the target yield, the depopulation would be avoided by that, extinction and aging of the total population, it is necessary to make a strategic decision on the allocation of budget funds for this purpose in an adequate amount (in some countries 1,6 to $3.2 \%$ ). Despite major problems with filling the budget at all levels and its deficit, a very complex and difficult economic situation, high unemployment, and a number of other adverse circumstances, a model is neccesary that can be easily further developed and quantified according to the long-term target birthrate of 11094 children per year level, that provides simple reproduction.

\section{CONCLUSION}

At the end of the eighties of last century $\mathrm{BiH}$ has entered the one of specific phase of its demographic development. The pattern of recovery of the population has been changed (below the level of simple reproduction), followed by the war events, particularly have hit the demographic trends. Population growth rate in $\mathrm{BiH}$ was 8.9 0/00 1991. a $-1.5 \%$ 2015. Bosnia and Herzegovina has entered a process of the total depopulation since 2007.

War period in Bosnia (1992-1995) has launched a large displacement of the population with a number of refugee waves and it has determined the atypical enforced substitution of the population of relatively large scale, as well as the redistribution of population within $\mathrm{BiH}$. Today outside $\mathrm{BiH}$ (in the Diaspora) there is a population of 1.6 million of its inhabitants. Demographic war Losses are one of the most important determinants of total depopulation. In other words, population of $\mathrm{BiH}$ has been significantly reduced between 1991 and 2013.

The depopulation process is the most widespread in the Republic of Srpska. Natural depopulation has been occurring since 2002, while the population growth rate in the Federation of $\mathrm{BiH}$ is almost at zero level $\left(-0.2^{0} \% 0\right)$. Over time depopulation process has expanded, so $\mathrm{BiH}$ has entered into the overall process of depopulation in the last eight years.

The strategic goal of $\mathrm{BiH}$ and its entities is reaching the level of so-called stationary population (equal number of births and deaths), and the preservation of the existing contingent of the population. In order to achieve this goal, it is necessary more than 11000 children to be born annually.

\section{REFERENCE LIST}

Marinkovic, D. (2010), Demografski razvoj i sprovodjenje mjera populacione politike u Republici Srpskoj, Novi Sad: Matica srpska br. 131. str.33-43.

Pasalic, S. Atropogeografska stvarnost Srba u BiH 1992-2000.(2002), Banja Luka: Banjaluka Kompani.

Pasalic S., i drugi (2006), Demografski razvoj i populaciona politika Republike Srpske, Bijeljina: Mladost

Pasalic, S. (2012) Demographic losses in Bosnia and Herzegovina. Republic Center for war crine research, Banja Luka/Hag: ICTY

Pasalic, S. (2013). Export report, Hag: ICTY

Pasalic, S. (2014), Demografska budućnost Republike Srpske - izumiranje stanovništva ili populaciona revitalizacija, Opstanak, Zbornik radova, Aleksandrovac.,str. 111-123.

Pasalic S. i sar. (2015), Demografski resursi i organizacija osnovnog obrazovanja u Republici Srpskoj, Glasnik Antropološkog društva Srbije, br. 49, str. 159-166.

Popis stanovništva u BiH, Agencija za statistiku, Sarajevo, 2016.

Statistički godišnjak Jugoslavije, 53-91. SZS, Beograd

Rogers, A. (1976). Demometrics of Migration and Settlement. Laxenburg: International Institute for Applied System Analysis (IIASA Research memorandum, RM-76-068).

Statistički godišnjak, 1993-1998., FZS, Sarajevo, 1998.

Statistički bileten, RZS, Banja Luka, 2014.

Tabeau, Ewa (2009). Rat u brojkama - demografski gubici u ratovima bivše Jugoslavij od 1991-1999. Beograd: Helsinški odbor zaljudska prava u Srbiji

Wertheimer-Baletic, A. (1999). Stanovnistvo i razvoj. Zagreb: Mate 